\title{
On British-American Special Relations through 9.11 Event
}

\author{
Renfeng Zhang \\ Institute of South Asian Studies, Sichuan University, Sichuan 610064, China \\ E-mail: zhangrenfeng258@163.com
}

\begin{abstract}
For a long time, America and Britain have been keeping a kind of special relations. Britain has always been the follower of America in many international issues, and paced with America accordingly. When 9.11 Event broke out, Britain still was the first one who wanted to cooperate with America to fight against terrorism. In the process of European integration, Britain was relatively isolated, known as "Europe's orphan". Strengthening the special relations with the United States, can not only enhance the status of the United Kingdom in Europe, but also can enhance Britain's standing in international affairs. Therefore, Britain seized the very opportunity to maintain consistency with the United States.

However, there were some serious conflicts of interest between Britain and the United States in other parts of the world. It seemed that there are no so-called special relations between them. From time to time, the United States was dragged on the British interest edge, mainly because Britain wanted the United States to bear some responsibilities for it, while Britain did not want itself to be the most powerful country as to bear the responsibility of maintaining the present situation.
\end{abstract}

Keywords: British-American, Special Relations, 9.11 Event

\section{The Origin of Special Relations and Historic Review}

\subsection{The Origin of the Term-Special Relations}

The term (special relations) is a phrase originated in the United Kingdom. It is used to characterize what British advocates as the positive political, diplomatic, historical, relations between the United States and member nations of the Commonwealth Nations or the United Kingdom. The phrase is almost exclusively used by British commentators and is often represented to mean the relations between the United Kingdom and the United States.

The origin of the term may be Winston Churchill's "Sinews of Peace Address" in Fulton, Missouri, better known for addressing the rise of communism and the Iron Curtain. British Prime Minister Winston Churchill first used the term in 1946 to describe the special relations between the US and the English speaking countries of the British Commonwealth. (Wen Xianjuan, 2003) However, Churchill first coined the term in a speech in 1945 . The phrase was used not to describe the UK-US bilateral relations but rather to describe his hope for a "special relations" between the UK and its transatlantic war allies, Canada. Practically, the United States maintains a close economic, cultural and military relations with Canada, and significant trade relations with other countries such as Mexico, Japan, Israel, etc. However, according to British author James Wither, the level of cooperation in military planning, execution of military operations, nuclear weapon technology sharing and intelligence sharing between the U.S. and UK is unparalleled.

Most American commentators had until relatively recently construed the special relations as a "one-way street", namely that Britain relied heavily on the United States to promote its affairs in international relations. This was certainly true from Post-Second World War Britain, until the resurgence of the British economy, after Prime Minister Margaret Thatcher's radical economic and social reforms during 1979 to 1990. Moreover, Thatcher had exceptionally close political and personal relations with US President Ronald Reagan, which contributed in part to the international political climate which ultimately led to the dissolution of the Soviet Union.

\subsection{Historic Review}

The friendly relations between the United States and Britain have experienced a long history. The following historical records can fully prove this point:

In April, 1917, the United States participated in the First World War, Britain and America formed the US-British coalition;

In July, 1940, America and Britain had secret negotiations, U.S transferred its warships to Britain, and Britain leased naval and air base to the US; 
In August, 1941, the leaders of Britain and America had Atlantic meeting, issued Atlantic Charter;

In November, 1942, American and British forces landed in North Africa, opened up North Africa, a new battlefield;

In January, 1943, the US-British summit was held in Casablanca to discuss a common strategy;

In July, 1943, the allied forces attacked Sicily, in September, Italy surrendered;

In June, 1944, the allied forces landed in the Normandy, opened a second battlefield;

In March, 1946, Winston Churchill visited the United States, gave a speech on alliance, and opened the curtain of Cold War;

In June, 1950, the Korean War broke out, Britain participated in the U.S.-based United Nations Army;

In October, 1956, the Suez Canal crisis erupted, the US-British relations suffered setbacks;

In April, 1982, the British-Argentine war broke out, the United States provided Britain with diplomatic and military support;

In January, 1991, Britain took part in the "Desert Storm" military action with the United States

In December, 1998, the United States and Britain together stroke Iraq by air which codenamed "Desert Fox" air strike;

In March, 1999, Britain took part in a large-scale air strike launched by the United States, in the name of NATO, against the Federal Republic of Yugoslavia;

In March, 2003, Britain actively involved in Iraqi War with the United States.

\section{British-American Cooperation Relations}

\subsection{Special Relations in Specific Areas}

\subsubsection{Special Relations in Politics}

The special relations between Britain and the United States started from the politics. As early as in the First World War, Britain and the United States formed their alliance, which was maintained to cope with the war.

For political system, Britain and the United States share the same two-party system, and the same form of government, which makes them come to a very similar political decision. Thus, this can speed up their special relations in politics. Britain was the first state who established a two-party system. (Xie Guanping, 2003) The establishment of United States precisely is the result of catching up with the accomplishment of the two-party system in Britain. It can be said that the two-party system of the United States entirely originated from the two-party system of Britain. In fact, in politics, America and Britain cooperated with each other, learned from each other and progressed mutually. This makes the relations between the two countries more intimate.

\subsubsection{Special Relations in Economy}

In the First World War, Britain and the United States forged their relations. After the war, the domestic economy of Britain had tumbled, which forced it to adapt to new environment. And this new environment was that Britain must rely on the United States. Before the war, Britain was the largest creditor nation in the world, But after the war, it has become a debtor country, owed the United States more than 40 billion dollars.

The Second World War made Britain more closely approaching the United States. The gradual decline in Britain's international status and national strength made Britain economically have to rely on other countries, especially on the United States. "Marshall Plan" which was launched by the United States in 1947 has played a very important role in the economic revitalization of post-war Europe. (Wang Zusheng, 1983) For the dilapidated Europe, such act of the United States is timely helpful. And for Britain, a country of Europe who had the closest relationship with the United States, appreciated the United States' charity of such kind. However, the implementation of "Marshall Plan" exacerbated the United Kingdom's economic dependence on the United States.

The United States is the largest source of Foreign Direct Investment to the UK's economy. Likewise the UK is the largest single investor in the US economy. British trade and capital have been important components of the American economy since its colonial inception. After 9.11 Event, their economy can be more relatively connected.

As of July 2006, the economy of the United Kingdom is the fifth largest national economy in the world (measured by GDP). The economy of the United States is the largest national economy in the world. The US is 
the biggest single investor in the UK, and vice-versa (figures for 2004). This economic strength, together with Britain's influence as one of the "big three" in the European Union, has altered the relative US/UK balance somewhat.

\subsubsection{Special Relations in Personal Relations}

The personal relations often depend on the personal relations between British Prime Ministers and U.S. Presidents. The first example was the close relations between Winston Churchill and Franklin Roosevelt who were in fact distantly related.

Prior to their collaboration during World War II, Anglo-American relations had been somewhat frosty. President Woodrow Wilson and Prime Minister David Lloyd George had enjoyed nothing that could be described as a special relations, although Lloyd George's wartime Foreign Secretary, Arthur Balfour, got on well with Wilson during his time in the United States and helped convince a previously skeptical Wilson to enter the war. Churchill, himself half-American, spent much time and effort cultivating the relations which paid dividends for the war effort though it cost Britain much of her wealth and ultimately her empire. Two great architects of the special relations on a practical level were Field Marshal Sir John Dill and General George Marshall whose excellent personal relations and senior positions (Roosevelt was especially close to Marshall) oiled the wheels of the alliance considerably.

The links were created during the war. However, when Britain wanted to gain benefit from the relations it became clear that a constant policy of personal engagement was required. Britain starts off in 1941 as somewhat the senior partner had quickly found itself the junior. The diplomatic policy was thus two pronged, encompassing strong personal support and equally forthright military and political aid. These two have always operated in tandem, that is to say the best personal relations between British prime ministers and American presidents have always been those based around shared goals. For example, Harold Wilson's government would not commit troops to Vietnam, Harold Wilson and Lyndon Johnson did not get on especially well.

Highlights in the special relations would include Harold Macmillan and John F. Kennedy or Margaret Thatcher and Ronald Reagan. Nadirs have included Wilson's refusal to enter the war in Vietnam and the American government's lack of support for British operations in Suez under Anthony Eden. While the relations between the two countries may have been strained by Reagan's neutrality in the initial phases of the Falklands War this was more than countered by the US Defense Secretary, Casper Weinberger, who approved shipments of the latest weapons to the massing British taskforce. Bill Clinton was poorly disposed towards John Major after it was alleged that the Conservative government had allowed his Republican opponents access to British documents detailing his time at Oxford University. Friction in their relations was also demonstrated when in March 1995 Major refused to answer the phone calls of Clinton over his decision to invite Sinn Fein leader Gerry Adams to the White House for Saint Patrick's Day.

\subsection{The Development of the Special Relations after 9.11 Event}

\subsubsection{Common Interests in Anti-Terrorism}

9.11 Event was of the most serious activity in the history of international terrorism, which aroused unanimous condemnation to terrorist activities by the people in the world. Only a week after the incident, 24 countries declared that they would support the United States to fight against terrorism, and to a varying degree, expressed their willingness to give specific help.

In combating terrorism, Europe and the United States have the same interests. After 9.11 event, EU (European Union) immediately expressed its sympathy to the United States and stressed its resolutions on combating terrorism with the United States. On September 21, 2001, an "anti-terrorism plan." was adopted on the EU Special Summit. (Robert. A. Bradtke, 2002) On September 30, the 75th Annual Meeting of Interpol (International Criminal Police Organization) decided to strengthen anti-terrorism cooperation. On October 3, NATO (North Atlantic Treaty Organization) took eight specific measures to help the United States to fight against terrorism. On October 6, the finance ministers of G-7 and the president of Central Bank had a meeting in Washington, on which both sides released a statement, and developed a "plan on combating terrorist activities." Britain was confused, on the one hand, it can work with the United States together to combat terrorism, deepen relations with the United States. On the other hand, he also had to consider the overall situation of Europe. Being close to the United States, it must consider whether its actions would affect the brother-like affection on Europe. He followed the United States to have anti-terrorism activities, adopting different forms from other countries, which couldn't have enraged other European countries. However, the national interest of anti-terrorism is of each country's strategic goal. 


\subsubsection{Cooperation Relations in Iraqi War}

2003, Iraqi War broke out. Britain positively participated in the war in order to maintain its partnership with America. However, EU strongly objected Britain's action while Britain desperately supported America. On the Council of United Nations General Assembly, the United States and Europe were in sharp opposition and fierce fight. On March 5, Foreign Minister of France, Germany and Russian Jointly appealed to continue weapons inspections and the three countries authorized a joint statement to oppose Britain and America taking the war against Iraq. In the isolated circumstances of no agreement on a new motion, Britain and the United States announced requirement on giving up the new motion on March 17. Meanwhile, they sent out Saddam an ultimatum, asking him for his leaving Iraq within 48 hours. Rejected, the coalition forces of Britain and America then on the evening of March 20 launched the largest "pre-emptive" and "preventive" war in American history, for the objectives which are possibly useful for military in Iraq.

\subsubsection{Relations during Post-Iraqi War}

Although the war on Iraq led by US with a coalition force didn't last for a long time, it has some lasting and deep effects on international economic and political relations. On the one hand, the war aggravated the conflicts of interests between the US and Europe. Even if Europe and the US have achieved some compromise after the war, their interest conflict will make them confront for a long period. Presently, both Europe and the US are facing the international terrorism and the threat of mass destructive weapons proliferation; On the other hand, under the present circumstance with America strong and Europe relatively weak, the security in Europe is still closely connected with the United States' cooperation. For their respective benefit, it is logical that they adjust to the crisis in Iraq and the standpoint of bilateral relations. Since American and the European economy relations are closed and the degree of the relations is mutually high, the interdependent degree of their economic relations is quite high.

After the Iraqi war, the US-European relations generally tended to become friendly. But they also have more conflicts since Iraqi War. That is because, firstly, they have different views on some areas, such as religious relief, national interest, demands in international world. The United States believes that the root causes of terrorism is evil, terrorist attacks, not religious reasons, not political reasons, the only motivation is evil. The Europeans consider that the United States has overestimated the terrorism and the danger carried by other threats and that the United States should herself hold part of responsibilities for the attacks. (Craig, Kennedy. and Marshall, M. Bnouton, 2002)

So, America and Europe have some common interest in anti-terrorism. But in the long run, they will combat for quite long. If there will be some unexpected incidents in the future, perhaps they will become reconciled.

\section{Further Study on British-American Special Relations}

\subsection{Influences on International World}

Britain and America's special relations showed a kind of unique international style for the people of the world, demonstrated the atmosphere of cooperation of the international community. At the same time, it also allowed many countries to see the unfairness of international politics and the ambition of several big powers wanting to dominate the whole world. The British-American special relations which have lasted nearly for a century deeply impacted and are still deeply impacting on the international community. The specific effects can be boiled down as following:

(1) Strengthened the cooperation between Britain and the United States, and made the United States more wantonly practicing "unilateralism" and "hegemony policy." In 1990s, when the disintegration of the Soviet Union committed, the United States was for a long time helpless, unable to find its enemy who could confront with it. This made the United States quite lonely in the international community. But later, America quickly introduced its "unilateralism" and "hegemony policy", and became more arrogant. That is mainly because other countries flattered America, particularly Britain. When it has quite a lot of collaborators, America begins to let it have its own way.

(2) Intensified the contradictions of the international community, and made the ideology in international politics more clearly displayed. When other countries cannot correctly deal with their international issues, they will have some hostility on the unusual acts, such as the British-American special relationships. As we know, both Britain and America are capitalist countries. Why can these two countries have so intimate relations? Some people may say that's because of the role of the ideology. Thus, the ideology in international politics can be more clearly displayed.

(3) Distracted the force of EU, upgraded the contradictions Between the United States and Europe, making 
the EU integration process more difficult. In Iraqi war, the core countries of the European Union represented by France, Germany refused to agree on United Nations' mandating America combating Iraq, based on their own interests and policy concept. They also strongly opposed the United States' unilateralism. It must be pointed out that the United States and Europe are of the same political system, and the common values, both of which advocate the principles including western democracy, freedom, human rights and market economy. But they have serious differences when they view the current norms of international relations and international agreements as well as international institutions and other issues.

\subsection{A Brief Analysis of British-American Special Relations}

Why can Britain have special relation with America? That is what many countries have asked for long. Historically, Britain and the United States were linked in blood. The Britons arrived in Plymouth by ship "May Flower" and became the first immigrants in the virgin land of North America. For hundreds of years, with the constantly increasing European immigrants, the North American region became a new nation based on English and Anglo-Saxon cultural background - the nation of the United States. And on this basis, United States of America was founded.

However, in the 150 years from the independence of the United States to the First World War, The relationship between Britain, the former sovereign state, and the "colony" which later won independence - the United States was not as harmonious as expected. The two countries have delicate differences in ethnic psychology. Only from the First World War did Britain begin to ally with America to resist powerful enemies, hoping to gain much more assistant from America. This was the moment Britain considered its own interest. It had no other ways to preserve its own strength but to beg the United States.

What stimulates them to act accordingly?

On the one hand, English government has been maintaining extremely close relationship with American former president Clinton's Democratic Party. When the new president of American Republican Party Bush was in power, he changed American foreign policy and the country concept which were different from Clinton's. It is sure to be difficult that Blair Labor Party is quite close with American Democratic Party in ideology. Blair's Labor Party and Bush want to maintain the same close relations as the Clinton era. The new U.S. government's using force against Iraq at the beginning of its taking office provided the Blair government a precious opportunity to show its true feelings in establishing good relations with the U.S new government. Britain committed having an air raid to Iraq with America, which is undoubtedly the best "gift on their first meet" Britain prepared for America. It was not only good for Britain's maintenance and development special relations with America, but has special importance for Blair Labor government who were striving to seek re-election.

On the other hand, the United Kingdom is no longer "the empire on which the sun never sets", its international position increasingly weakened, even its position in Europe could not compare with its past. In the process of European integration, Britain was relatively isolated, known as "Europe's orphans". (Zhao Huaipu, 2004) Strengthening the special relationship with the United States can not only enhance the status of the United Kingdom in Europe, but can enhance Britain's voice in international affairs and guarantee its safety. Therefore, Britain seized the very opportunity to maintain consistency with the United States.

When America militarily stroke against Afghanistan, Britain actively took part in the combat, only to dispatch aircraft and aircraft carrier army. But the other NATO (North Atlantic Treaty Organization) members just waited or watched in safety while others fighting, sometimes had the verbal support.

It could be said that Blair put his ass on the line for Bush. In fact, Britain and America for long has been cooperating with each other, especially in personal relations. During the Second World War, British Prime Minister Winston Churchill and America president Roosevelt kept a kind of more unusual relations. Then they had been friends long ago. When Churchill was British admiral, Roosevelt wrote to him frequently, and Churchill often told Roosevelt British fighting situation in the Atlantic Ocean, some of the news even Churchill's chief executive did not know. In 1982, Britain and Argentina came into diplomatic disputes. Argentina dispatched only an aircraft carrier and occupied Falklands. Four days later, the "Iron Lady" in Britain Congress swore in speech: "the flag of the British Empire must be re-raised in the Falklands!" British Parliament unanimously adopted the program dispatching troops to occupy Falklands. However, few countries supported sending troops to Argentina. American politicians also dissuaded the president Reagan from acting rashly. While smart Mrs. Thatcher hinted Reagan that Argentine problem is the best opportunity to test the US-British relationship. Finally, Reagan firmly chose Thatcher.

Throughout British-American post-war Special Relations, we can see that the goal of British foreign policy was 
to maintain the pre-war status as a great power, while America's foreign policy goal was to guarantee its leading position in the world. There were some serious conflicts of interest between Britain and the United States in other parts of the world. It seemed that there is no so-called special relation between them. From time to time, the United States was dragged on the British interest edge, mainly because Britain wanted the United States to bear some responsibilities for it, not want it to be the most powerful country to bear the responsibility of maintaining the present situation. The followers of the special relations declared that the special relations between Britain and America is just the spirit ally of the west, a kind of inter-understanding based on power, money and brave acts.

\subsection{Lessons for China's Diplomatic Policy}

After 9.11 Event, the international environment of China's socialist construction is becoming more complex and changeable. It indicates that the factor of promoting countries (especially great nations) to strengthen coordination and cooperation is also increasing. The worldwide peace strength is still growing. China's peaceful construction is still guaranteed.

At the time being, China is on its way to desperately develop its economy. To gain a good environment for China's development, proper diplomacy is very indispensable. Through British-American Special Relations, we can clearly realize the international situation and can well prepare to win initiative in the international society.

After 9.11 Event, the Britain-American relations are becoming more intimate. English, as the common language of them, has become the world language. The mainstream of Britain and the United States' jointly leading the world is become more and more obvious. For 9.11 Event, China actively clarified its attitude on terrorism, and resolutely opposed terrorism, advocated the establishment joint action mechanism on international anti-terrorism led by United Nations. All efforts China had made received supports and endorse from the majority of countries in the world. The relations among China and some powers in the world have been strengthened and improved to different degrees. However, we must know that 9.11 Event has also brought some negative impact on China's international relations and international environment. And some new issues arose as well. Only we have clearly recognized the international situation and strive for obtaining more help from other nations can we be in an invincible position in the international society.

\section{Conclusion}

Britain and America has been keeping a kind of "special relations" since the Second World War. However, with the cold war finished, the U.S devoted to adjusting its strategy, from emphasizing Europe to promoting its "Two-Ocean Strategies", started to emphasis at Asia. England's status in America's global strategy dropped, "the special relations" day after day had been squeezed out to the American diplomacy edge. Especially since Clinton was in power, the two countries' relations had greatly changed palely. However, in the American mind, England still was an important partner which had influence on the world. The development of internal federalism in European Union caused the European skeptics in English interior had more vigilance. Thus, Britain turned to more emphasis on developing relations with nations who are non-EU's, including nations in area of North America and Southeast Asia. This kind of situation again provided an opportunity for Britain and America to patch their relations.

The anti-terrorism cooperation after 9.11 Event has brought their special relations to the high tide, also has pushed it up to the front-stage on which they also have current diplomatic conflicts. Obviously, the limitation and vulnerability of this kind of special relational exposed. First, Britain and America still has difference and contradiction in their diplomatic thought and strategic target. In current situation, if unilateral principle and hegemony thought continue to be America's main foreign policy, military method and unilateral arbitrary continue to dominate its diplomatic means and its multi-lateral consultation. Britain's "restraint with good intentions" will be difficult to moderately influence on America's foreign policy. America will also be difficult to act as Britain expected, as to become "the benign hegemony" advantageous to the international order construction.

Further more, because of the strength disparity between Britain and America, to "share leadership" with America will extremely become the possibility of Britain's one-sided wish. The essence of their special partnership is not as expected as Britain's, or, just as relations between master and servant. In America's global strategy, Britain is an important chess on board. If so, Britain's importance cannot be compared with nations who are regarded by America's competitors, such as Russia, China and Japan. Britain is different from Germany and France which are as America's allies who frequently persisted with their own standpoints in international affairs. Once the situation changes, Britain's status in America's strategy will be lower, their special relations will also be avoided receding. 
Therefore, if Britain closely ties up its own benefit and the "rationality" in current pattern, it will extremely become hindrance as conservative forces, its original intention of repairing the unilateral principle and establishing proper international order will be encountered questions, and its status outside America in the world will also be isolated day after day.

\section{References}

Craig, Kennedy. and Marshall, M. Bnouton. (2002). The Real Trans-Atlantic Cap. Foreign Policy, Issue 133, P. 70.

Development of the world Situation. (2004). Beijing: Current Affairs Press, p. 5, p. 12, p. 34, p. 46.

Foreign and Commonwealth Office Annual Report. (2001). Ninth Report of the Foreign Affairs Committee, Session, 2000-2001, p. 5, p. 13.

House of Commons. (2001). Second Report: British-US Relations, British.

Prime Minister's Iraq statement to Parliament. (2002). [Online] Available: http:// www.pm.gov.uk.

Robert. A. Bradtke. (2002). Deputy Assistant Secretary for European and Eurasian Affairs. USA, NATO Enlargement, testimony before the House International Relations Committee.

The White house. (2002). The National Security of the United States of America, p. 4.

Wang, Zusheng. (1983). History of International Relations. Wuhan, China: Wuhan University Press, p. 157, p. 369.

Wen, Xianjuan. (2003). On British-American Relations during the Suez Canal Crisis. [Online] Available: http://scholar.ilib.cn/Abstract.aspx?A=1sjx200310011, p. 3 .

Xie, Guanping. (2003). English of politics and law. Hefei, China: University of Science and Technology of China Press, p. 24.

Zhao, Huaipu. (2004). Britain and European Integration. Beijing, China: World Affairs Press, p. 145, p. 278. 